\title{
Artistic responses to Darwinism
}

Darwin: Art and the Search for Origins Shirn Kunsthalle, Frankfurt, Germany Until 3 May 2009

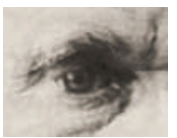

When he boarded HMS Beagle, Charles Darwin made room in his luggage for a copy of Alexander von Humboldt's Darwin200 Personal Narrative, the account of the German explorer's 1799-1804 journeys in Latin America. Humboldt's view of the natural world was a major influence on the young Darwin, until his own experiences led him to a different interpretation. Where Humboldt the romantic saw unity and harmony, Darwin the scientist saw strife and struggle.

With the spread of illustrated print magazines, artists of the time could hardly overlook the debate among scientists, theologians and philosophers over Darwin's destabilizing theories of evolution and ruthless natural selection. The exhibition Darwin: Art and the Search for Origins, running until 3 May at the Shirn Kunsthalle in Frankfurt, Germany, looks at how artists responded in the century following the publication of Darwin's On the Origin of Species.

Some of the works are straightforward attempts to promote one side of the argument, but most incorporate concepts that evolutionary theory made inevitable, such as 'deep time.' Not all of the displayed works embrace Darwinism; for example, those of Frederic Edwin Church (1826-1900) tried to reconcile geological and religious accounts of Earth's history in support of anti-evolutionist positions. But the attitude of his contemporary, Martin Johnson Heade (1819-1904), shifted in favour of Darwinism as he became more familiar with it - as his sublime late series on hummingbirds and orchids shows.

Some of the most interesting artistic responses to Darwinism happened in Germanspeaking countries in the intellectual wake of Humboldt. The exhibition includes many works by Ernst Haeckel (1834-1919), the German scientist and artist who promoted Darwin's theories in continental Europe with his exquisite illustrations of sea creatures, particularly

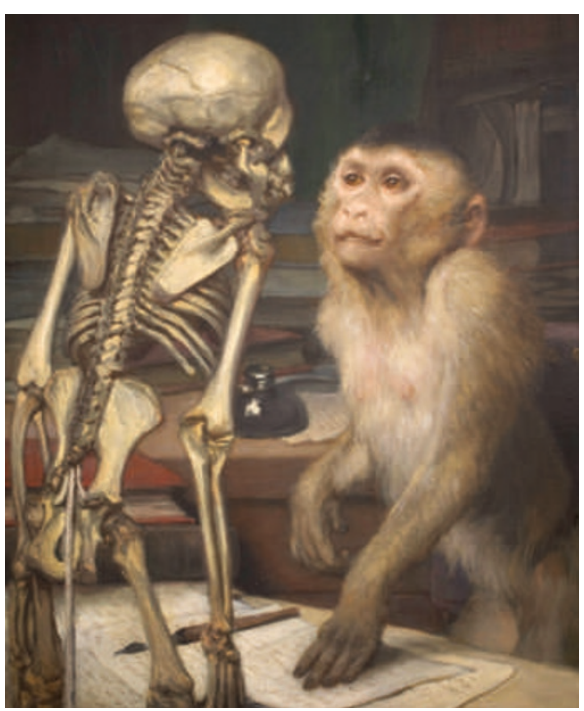

the radiolarians. But it is also replete with works less well known as Darwinian.

Arnold Böcklin's Meeresidylle (1887) references the evolutionary continuity of humanity with creatures of the sea. It was painted a few years after the Swiss artist forged a friendship with Anton Dohrn, a former student of Haeckel who established a zoological institute in Naples, Italy. The institute's mission was to collect empirical data substantiating Darwin's ideas. Böcklin's work was steeped in mythology, and few critics understood it. Karl Scheffler was an exception: in 1921 he proclaimed Böcklin to be "the painter and poet of Darwinism".

The exhibition also contains works by the convinced Darwinist, Gabriel von Max (1840-1915). As a friend of Haeckel, von Max was a passionate naturalist, but eventually departed from Haeckel's view that humans were the pinnacle of Darwinistic achievement. He came to prefer the pet monkeys he used as models, painting them carrying out human activities (as in Monkey Before A Skeleton; pictured, left) such as teaching or learning. In another famous image, his monkeys are portrayed as art critics (see Nature 438, 289; 2005).

A successful artist in his day, von Max made enough money to accumulate a vast collection of more than 60,000 zoological, anthropological and ethnological objects. Sold to the German city of Mannheim in 1917, renowned prehistorian Carl Schuchhardt described it as "the richest and most interesting private collection in the field of science since the death of Goethe". Part of this collection is included in this thought-provoking exhibition.

Alison Abbott is Nature's senior European correspondent.

\section{The body as a commodity}

Biofutures: Owning Body Parts and
Information
by Robert Mitchell, Helen J. Burgess
and Phillip Thurtle
Penn Press: 2008. $\$ 39.95, € 26$ (DVD-ROM)

It is appropriate that a commentary on the possible futures and dangers associated with owning parts of the body - a discussion anchored in biology as information - should be presented as a hypertext DVD rather than as a conventional book. Biofutures deploys multimedia information sources, including video, text, interviews, film clips, web links and animations, all accessed through a central menu. The interactive format allows for nonlinear exploration of the three main themes of law, biology and culture, and users may create their own links with digital bookmarks that can be managed with password protection.

Each theme is subdivided into two chapters based on case studies that have been marked by controversy. In the law section, the case of John Moore in the United States is highlighted by the resulting dispute over the patenting of cell lines derived from his tissue. The DVD also investigates the creation of the patient lobby group PXE International to promote research on the genetic disease PXE, pseudoxanthoma elasticum, and the tensions this created between the community and individual patient rights.

Biology is discussed through the case of the Nexia spider goat, the transgenic goat that contains spider genes that produce a silk-based material in the goat's milk. The lightweight but strong 'biosteel' will make biodegradable cables with multiple industrial applications. In another case study, the use of cryonics to freeze bodies offers a chance to explore the control of biological clocks in the lab and how this relates to wider economic and financial temporalities.

The section on culture discusses the role of biology-based art as a form of science, a form of critique and a disrupter of natural boundaries. An extended commentary on the fictitious narrative of the films Jurassic Park and Resident Evil tells us about different possible futures.

Each case study takes about 30 minutes to read and listen to, with an accessible range of clips, interviews and images on each page. Pitched at undergraduate students, it is designed to be used as a teaching aid, bolstered by additional detailed reading. Most sections provide background material, often filmed in labs, such as the creation of immortal cell lines that are key to understanding the John Moore case. 